\title{
粚
}

\section{Grammaties-historiese eksegese: quid est et quo vadis?}

\author{
H.J.M. van Deventer \\ Eenheid vir Reformatoriese Teologie \\ Skool vir Basiese Wetenskappe \\ Fakulteit Geesteswetenskappe \\ Vaaldriehoekkampus \\ Noordwes-Universiteit \\ VANDERBIJLPARK \\ E-pos: hans.vandeventer@nwu.ac.za
}

\begin{abstract}
Grammatical-historical exegesis: quid est et quo vadis?

This article investigates the grammatical-historical method of biblical interpretation. The aim is to indicate certain problems in the approach through critical investigation and to make suggestions regarding changes to this method. Emphasis is placed on the historical- and reader-focused aspects related to reading an ancient biblical text. The development of the grammaticalhistorical method is placed against the backdrop of the development of biblical interpretation in general. Lastly, suggestions are made on how the results of the historical-Jesus research can contribute to responsible exegesis.
\end{abstract}

\section{Opsomming}

\section{Grammaties-historiese eksegese: quid est et quo vadis?}

Hierdie artikel neem die grammaties-historiese metode van Bybelverklaring onder die loep. Die doel is om by wyse van kritiese ondersoek, bepaalde leemtes in die benadering uit te wys en voorstelle te maak met betrekking tot die aanpassing van hierdie metode. Klem word veral gelê op die histories- en leser-gefokusde aspekte wat by die lees van 'n antieke Bybelteks ter sake is. Die ontwikkeling van die grammaties-historiese metode word teen die agtergrond van die ontwikkeling van Bybelverklaring in die algemeen geplaas. Laastens word voorgestel hoe resultate van ondersoeke na die historiese Jesus 'n bydrae tot verantwoorde eksegese kan maak. 


\section{Inleidend}

'n Dinamiese ruimte bestaan tussen 'n leser en die teks waarmee die leser besig is. Oor die algemeen is lesers onbewus van hierdie ruimte aangesien die leser en die teks meestal dieselfde sosio-historiese milieu deel. Hierdie milieu sluit in aspekte soos taal, tydsgewrig en die vlak van leesvaardigheid, om maar enkeles te noem. Eers wanneer die leser en die teks nie sodanige milieu deel nie, kan eersgenoemde dalk bewus raak van die bestaan van hierdie ruimte - oftewel die afstand tussen hom/haar en die teks. Die verstaansprobleem raak, menslik-gesproke, net soveel dringender wanneer met religieuse tekste uit die antieke era (soos die Bybelboeke) gewerk word (Kaiser \& Silva, 1994:19). Dit is deel van die rede waarom daar binne die akademiese konteks metodes ontwikkel is en steeds ontwikkel word wat poog om hierdie ruimte te oorbrug.

Die boeke van die Bybel, soos ook die meeste ander tekste, is geskryf om verstaan te word. ${ }^{1}$ Die vraag waarop hierdie artikel fokus, is na die geslaagdheid, al dan nie, van 'n bepaalde metode waarmee die tekste van die Bybel binne 'n huidige konteks verstaan word. Die metode onder bespreking is eie aan die gereformeerde teologie, en meer spesifiek, dié van die Teologiese Skool in Potchefstroom. ${ }^{2}$ Aangesien die metode deurslaggewend is vir die antwoord wat verkry word, is dit noodsaaklik om alle metodes krities onder die loep te neem. Alvorens by die grammaties-historiese metode stilgestaan word, word 'n oorsig gegee van die verskillende maniere waarop die Bybel deur die geskiedenis verstaan is.

$1 \quad$ Binne die postmoderne konteks is dit egter veral die Dekonstruksiebenadering wat agterdogtig is oor tekste se vermoë om te kommunikeer; of meer spesifiek, samehangend te kommunikeer, sonder dat die teks sigself in die proses "weerspreek". Die versamelwerk, The postmodern Bible (1995:129), verwoord dit aldus: "Deconstruction is suspicious of any view that there is a natural fit between language, world, and meaning."

$2 \quad$ Ek het nooit die voorreg gehad om in sy klas te sit nie, maar ek sou wel daarop wou aanspraak maak dat ek en prof. Tjaart van der Walt later van tyd oor 'n afstand kollegas was. Dit vanweë die gemeenskaplike band wat die Vakgroep Teologie op die Vaaldriehoekkampus van die Noordwes-Universiteit, en Mukhanyo Theological College albei met die Fakulteit Teologie op die Potchefstroomkampus van die NWU deel. Dit is 'n eer om hierdie artikel, 'n verwerking van 'n intreerede wat gedurende 2009 gelewer is, vir hierdie bundel aan te bied. 


\section{Die verstaan van die Bybel deur die eeue ${ }^{3}$}

Metodologie is 'n saak wat in elke vakwetenskap voortdurend op die tafel is, omdat 'n verband bestaan tussen metodes wat gebruik word en oplossings wat vir bepaalde probleme aangebied word. Soos die geval in vele vakwetenskappe is, is daar ook in die Bybelwetenskappe meer as een interpretasiemetode om te volg. Alle metodes is hoofsaaklik op algemeen aanvaarde beginsels in die vakgebied gebou, alhoewel dit ook gebeur dat selfs hierdie primêre beginsels binne 'n bepaalde vakgebied kan verskil. 4

\subsection{Bybelverstaan in die Bybel}

'n Goeie plek om te begin wanneer die verhaal oor die verstaanbegrip van die Bybel vertel word, is sekerlik by die Bybel self. Reeds in sommige tekste in die Bybel is aanhalings en interpretasies van boeke te vind wat ook deel vorm van die kanon. Vanuit 'n literatuurwetenskaplike hoek, sou hierna as 'n bepaalde vorm van intertekstualiteit verwys kan word. $\mathbf{5}$ Hierdie verwysings na ander tekste gee 'n mens enersyds ' $n$ blik op die proses van kanonisering waarvolgens bepaalde religieuse tekste oor die tyd heen deur geloofsgemeenskappe as gesagvol erken en aanvaar is. ${ }^{6}$ Andersyds her-

3 Hier word slegs 'n oorsig gegee. Baie werke oor hierdie aspek het al die lig gesien; die jongste hiervan is die eerste twee van vier volumes (Reventlow, 2009a; 2009b) wat onlangs verskyn het. Sonder hierdie historiese oorsig sou dit moeilik wees om die metode onder bespreking binne 'n breër konteks te plaas.

$4 \quad$ In die Bybelwetenskappe bestaan voorbeelde van verskillende metodes wat binne dieselfde denkraamwerk nagevolg word, terwyl daar ook verskillende denkraamwerke binne hierdie veld is (vgl. Van Deventer, 2005a). Van Seters (2009) se reaksie op Aichelle et al. (2009) is 'n resente voorbeeld van 'n debat tussen opponerende denkraamwerke.

$5 \quad$ In die laaste deel van die twintigste eeu het persone soos Kristeva (1969) die teoretiese onderbou in hierdie veld meer volledig uitgewerk (vgl. Moi, 1986). In die Bybelwetenskappe het hierdie benadering ook inslag gevind (vgl. Fewell, 1992; Aichele \& Phillips, 1995). Plaaslik het Snyman (2008) onlangs in hierdie verband gepubliseer.

$6 \quad$ Vergelyk McDonald (2007) vir 'n omvattende oorsig en literatuur. Met betrekking tot die Ou Testament bestaan konsensus dat kanonisering in fases plaasgevind het. Hierdie proses is volgens die tradisionele standpunt waar te neem in die drieledige indeling van die Hebreeuse Bybel, te wete die Wet (Torah), Profete (Nebi'im) en Geskrifte (Ketubim). Wanneer die boeke van die Hebreeuse Bybel finaal as gesagvol erken is, is egter nog in dispuut en voorstelle in hierdie verband strek ongeveer oor 'n 300-jaar tydperk (150 VHJ-150 HJ). Die begrip kanonisering, met die betekenis van 'n lys amptelike geskrifte, dateer eers uit 
inner dit aan die feit dat die Bybel nie as bundel in die antieke tyd bestaan het nie. Bybelboeke is op papirus of perkament geskryf, wat vir bewaring opgerol en telkens tydens voorlesing of bestudering afgerol is. Na verloop van tyd en as gevolg van noodwendige verwering, moes hierdie manuskripte per hand gekopieer word. In die vroeg-Christelike era sou kodekse, wat 'n primitiewe vorm van die hedendaagse boek verteenwoordig, die eerste tree wees om meer "boeke" saam te bind en so te bewaar. Die boekdrukkuns (vyftiende eeu) het die gerief gebring om 'n versameling boeke (soos die 36 boeke in die geval van die protestantse Bybel) in 'n hanteerbare formaat saam te bind. Aanhalings van die Bybel in die Bybel, dateer egter uit die antieke tyd en is grootliks, wat die Ou Testament betref, aanhalings uit aparte boekrolle.

Wanneer verwysings in die Bybel na ouer boekrolle bestudeer word, vorm 'n mens ' $n$ idee hoe die teks binne antieke kontekste verstaan is. Let byvoorbeeld op die verwysing in Daniël 9:2 na die woorde van Jeremia 25:11-12 met betrekking tot die tydperk van die ballingskap.

In sy eerste regeringsjaar het ek, Daniël, uit die Skrifte vasgestel dat volgens die woord van die Here wat tot die profeet Jeremia gekom het, Jerusalem sewentig volle jare 'n puinhoop sou wees. (Dan. 9:2 - NAV.)

Hierdie land sal 'n verlate puinhoop word en al hierdie nasies sal sewentig jaar lank die koning van Babel se onderdane wees. Maar wanneer die sewentig jaar om is, sal Ek die koning van Babel en daardie nasie in Galdeërland straf vir al hulle sondes, sê die Here. Ek sal hulle land vir altyd verwoes laat lê. (Jer. 25:11-12 - NAV.)

Wanneer die Daniëlteks met aandag gelees word, val dit op dat die skrywer(s)/samesteller(s) van die Daniëlboek nie die Jeremiateks letterlik verstaan het nie. Volgens 'n letterlike interpretasie van die Jeremiateks sou die tydperk waartydens Jerusalem (en miskien meer spesifiek die tempel) na die Babiloniese verwoesting in puin lê, sewentig jaar wees. In die Bybel vind 'n mens by die Kronis hierdie meer letterlike interpretasie (vgl. 2 Kron. 36:20-22). ${ }^{7}$ In Daniël 9:24

die vierde eeu en dit is anachronisties om die begrip met verwysing na 'n vroeër konteks te gebruik (vgl. Barton, 1997:20, 30-31).

So is die woord van die Here vervul wat deur middel van Jeremia gekom het. Die ballingskap het aangehou totdat die land vir sy sab- 
keer die engel, wat eie aan apokaliptiese literatuur vir Daniël 'n uitleg bied, die voor die hand liggende betekenis van Jeremia 25:1112 op sy kop. 8

Daar is sewentig tydperke vir jou volk en vir jou heilige stad vasgestel (Dan. 9:24a - NAV.)

Die weergee van 'n betekenis wat van die letterlike woorde in die teks verskil, sluit aan by 'n meer algemene tendens waarvolgens lesers in antieke tye religieuse tekste hoofsaaklik figuurlik verstaan het (Yarchin, 2004:xii). ${ }^{9}$ Volgens Yarchin (2004:xii) beteken dit nie dat die bedoeling van die outeur nie vir die antieke leser belangrik was nie, maar dat die figuurlike betekenis juis gesien is as die betekenis wat die outeur in gedagte sou gehad het. Wanneer dit by religieuse tekste kom, is verwag dat die teks meer betekenis sou hê as bloot die woorde wat neergeskryf is. Die doel was nie soseer om 'n verskuilde betekenis bloot te lê nie, maar om deur middel van 'n figuurlike lees in die goddelike gedagte te deel.

Indien 'n mens hierdie meer algemene opmerkings konkreet sou maak in die konteks van die Nuwe-Testamentiese gebruik van die Ou Testament, blyk iets soortgelyks. Enns (2005:132-142) toon aan dat die Bybelskrywers in hulle gebruik en verklaring van die Ou Testament in Nuwe-Testamentiese geskrifte by die interpretasiemodel(le) uit die antieke konteks aansluit. Hulle interpretasies steun in sommige gevalle selfs op buite-bybelse hermeneutiese tradisies, wat uit die destydse konteks afkomstig is. ${ }^{10}$ Enns (2005:117) merk op dat die oorspronklike konteks waarbinne 'n teks verstaan moet

\footnotetext{
batsjare vergoed is. Die hele tyd dat die land woes gelê het, het dit 'n Sabbatsrus geniet, 'n volle sewentig jaar. In die eerste regeringsjaar van koning Kores van Persië is die belofte vervul wat die Here by monde van Jeremia gegee het: die Here het dit bewerk dat koning Kores van Persië besluit het om dwarsoor sy ryk 'n proklamasie te laat afkondig.
}

$8 \quad$ Vergelyk Collins (1993:352): “The angel's explanation departs from the plain sense of the text." 'n Verbeeldingryke voorstel vir die verstaan van die "sewentig tydperke" is onlangs deur Athas (2009) aan die hand gedoen en verdien verdere aandag binne Daniëlnavorsing.

$9 \quad$ Figuurlike interpretasie is nie tot die antieke tyd beperk nie en kom steeds in die moderne tyd voor waar die Bybel in godsdienstige kontekste verklaar word. Daar verskyn selfs akademiese werke wat ondersoeke van hierdie aard aanpak (vgl. Walters, 2008). hede. 
word, nie tot taal en geskiedkundige aspekte beperk is nie, maar ook die hermeneutiese konteks behoort in te sluit.

Die Nuwe-Testamentiese interpretasies was verder daarop gemik om aan te dui hoe die Ou Testament sy doel in Christus bereik. Hierin vind 'n mens 'n meer religieuse (teologiese) beweegrede wat die Nuwe-Testamentiese outeurs se interpretasie rig, bo en behalwe die aansluiting by die destydse interpretasiemodelle. Hieronder sal weer daarna verwys word dat hierdie twee aspekte, die historiese en die religieuse, in voortdurende (kreatiewe) spanning met mekaar is (vgl. 3.4). 11

\subsection{Bybelverstaan tot en met die Middeleeue}

Wanneer buite die blaaie van die Bybel beweeg word in 'n poging om die verstaan van die Bybel, en meer spesifiek die Ou Testament, te karteer, is die eerste belangrike halte die Bybelinterpretasie van die Qumran-gemeenskap. Hierdie Joodse gemeenskap wat in afsondering langs die Dooie See gewoon het, was deels tydgenote van die Nuwe-Testamentiese skrywers en het grootliks dieselfde kulturele milieu gedeel. In gevalle waar hierdie tekste verklarings van Ou-Testamentiese tekste bied (bv. van die boek Habakuk in $1 \mathrm{QpHab}$ ), val dit op dat die verklarings geen gewag van die outeur se moontlike (historiese) bedoeling maak nie. Enns (2005:131) verwoord dit soos volg: "For the Qumran community, biblical interpretation was not a means of discovering ancient meaning but of using the Bible to validate the present self-understanding of the Qumran community." In hierdie proses is baie meer in die teks "ingelees" as wat die woorde op sigwaarde sou toelaat. Dikwels is op 'n figuurlike betekenis gesteun ten koste van die letterlike betekenis (Bray, 1996:60). ${ }^{12}$

Die spanning tussen 'n letterlike en figuurlike betekenis loop soos 'n goue draad deur die grootste deel van die Bybelverklaringsgeskiedenis. ${ }^{13}$ In die bestudering van byvoorbeeld die derde-eeuse kerk-

11 Guthrie (1977:107-108) het 'n geruime tyd gelede reeds die rede vir hierdie spanning in 'n moderne konteks soos volg verwoord: "[In] the pre-critical period ... historical background was considered to be irrelevant in view of the dogmatic approach to the text".

12 Vir meer inligting omtrent die interpretasie van die Bybel in die Qumrangemeenskap, kyk Flint (2001).

13 Benewens die verwysing na Qumran word nie verder op die ontwikkeling en diverse aard van Bybelinterpretasie in die Joodse konteks ingegaan nie (vgl. 
vader Origenes (ca. 185-254 n.C.) (wat al as die eerste en selfs grootste Christen Bybelwetenskaplike op die Afrika-kontinent beskryf is), ${ }^{14}$ vind 'n mens 'n eksponent van daardie lyn wat meer klem lê op figuurlike verstaan van die teks. Die rede hiervoor was die konteks waarin hy homself bevind het. Die Egiptiese stad Aleksandrië aan die kus van die Middellandse See, opgerig deur die Griekse wêreldheerser Aleksander die Grote in $332 \mathrm{VHJ}$, was gedurende die tyd van Jesus ook die tuiste van Philo, 'n Joodse geleerde. Hy het gepoog om Judaïsme met die heersende Griekse denke en filosofie te versoen, en het onder andere ook 'n allegoriese of figuurlike verstaan van die Hebreeuse Bybel voorgestaan. Volgens hom was sommige stellings in die Bybel onmoontlik, inkonsekwent, of bloot nie waardig genoeg om deel van 'n goddelike geskrif te vorm nie. Hierdie gedeeltes moes volgens Philo eerder allegories (figuurlik) verstaan word.

Philo se idees het voortgeleef onder die vroeë Christene in Aleksandrië wat uit die Joodse gemeenskap ontstaan het. Een van die eerste gesiene leiers van die kerk in Aleksandrië, Clement, het by Philo se benadering aansluiting gevind en is deur Origenes nagevolg. Die letterlike betekenis van die teks is volgens Origenes wel bruikbaar om eenvoudige mense te leer, maar van meer wesenlike belang was die dieper morele en geestelike betekenisse van die teks (Young, 1992:10).

Teenoor die Aleksandrynse vorm van interpretasie staan die Antiochiese interpretasietradisie, waarvan die naam ontleen is aan die sentrum van die vroeë Christelike kerk in Sirië. Yarchin (2004:76) voer aan dat die tweeledige kulturele invloed in hierdie streek (Semities enersyds, en Grieks-Romeins andersyds), die konteks geskep het waarbinne 'n eksegetiese tradisie kon ontwikkel wat meer op die letterlike (historiese) betekenis van die teks gefokus het. Een van die groot eksponente van hierdie skool, die kerkvader Theodorus van Mopsuestia (laat vierde tot vroeg vyfde eeu), het die resultate van die Aleksandrynse vorm van allegoriese interpretasie as fabelagtig beskryf. Self het hy baie meer op die letterlik-historiese betekenis van die teks gefokus (Bray, 1996:106).

Jasper [2004:25-28] vir 'n kort en Bray [1996:47-63; 11-167] vir 'n meer gedetaileerde bespreking van Joodse denkskole).

14 Vergelyk Bray (1996:83): "By any standard of measurement, Origen was the greatest biblical scholar of antiquity." 
Met die aanbreek van die Middeleeue het die figuurlike (allegoriese) verstaan van die teks steeds die botoon gevoer in die kerk se verstaan van die Bybel. Tydens die Middeleeue het daar 'n duideliker onderskeid gekom tussen wat tot dusver as "figuurlike" of "allegoriese" vorms van Bybelinterpretasie beskryf was. Dit het veral beslag in die ontwikkeling van ' $n$ viervoudige verstaan van die teks gekry. 15 Die volgende vers gee die aard van hierdie vorm van verstaan akkuraat weer (vgl. Scheffler, 1991:65).

Littera gesta docet, quid credas allegoria; Moralis quid agas, quo tendas anagogia.

Letterlik wys wat het gebeur, wat jy moet glo die allegoriese; die morele wat jy moet doen, waarheen jy gaan die anagogiese.

Die klassieke voorbeeld wat Bybelwetenskaplikes gebruik om die viervoudige vorm van verstaan mee te verduidelik, hou verband met verskillende betekenisse wat die "stad Jerusalem" sou hê: letterlik is dit die hoofstad van Juda; allegories verwys dit na die strydende kerk op aarde; moreel beteken dit die siel van die gelowige; en anagogies verwys dit na die hemelse stad, oftewel die triomferende kerk (vgl. Bray, 1996:147).

Vir hierdie bespreking is veral drie sake van belang. Die eerste hou met die verstaan van die begrip littera verband. Montague (1997:53) bied die volgende verduideliking aan van hierdie begrip: "The literal sense concerned not precisely the author's intended meaning as we understand the literal sense today but rather the events narrated, hence history." Hy verduidelik dat juis omdat die letterlike betekenis tot die feite van die verhaal beperk bly, 'n ander manier gevind moes word om by die "geestelike" betekenis uit te kom. ${ }^{16}$ Vandag sien verklaarders die "geestelike" betekenis as deel van die outeur se oorspronklike bedoeling (Montague, 1997:222).

Tweedens het hierdie viervoudige metode van verstaan daartoe gelei dat die interpretasie van die Bybelteks die alleenmandaat van goed-geskoolde kerklike voorgangers was. Die gewone kerkganger se begrip was tot die letterlike woorde van die verhaal beperk. Slegs

15 Montague (1997:52) wys daarop dat die onderskeid tussen vier vlakke van betekenis alreeds in die vyfde eeu deur Cassianus voorgestel is, maar dit is veral tydens die Middeleeue toegepas.

16 Hierdie aspek word soms onderwaardeer wanneer krities na allegoriese interpretasie gekyk word (vgl. Scheffler, 1991:68). 
die geleerde leiers kon die stap vanaf die letterlike woorde na die figuurlike (geestelike) betekenis neem. Bray (1996:146) wys daarop dat hierdie geleerdheid gesentreer was in kloosterskole, soveel so dat selfs plaaslike kerklikes "were often just as ignorant as their flock".

Derdens het die geskiedenisbeskouing gedurende die Middeleeue baie van 'n moderne siening verskil. Die letterlike betekenis van die teks vertel bloot wat gebeur het. ' $n$ Historiese bewussyn, wat mense daarop attent maak dat 'n huidige konteks van vroeëre kontekste verskil. en die rol wat interpretasie in die weergee van gebeure speel, was grootliks afwesig en het eers tydens die Renaissance op die voorgrond getree. Geskiedenis is vir die lesse wat daaruit geleer kon word, bestudeer en was nie daarop ingestel om verskillende weergawes van gebeure te vergelyk nie. Die gebrek aan 'n historiese bewussyn het beteken dat daar geen rede was om die feite te bevraagteken nie. Die Bybelse geskiedenis, soos dit letterlik opgeteken is, was veel meer 'n opvoedkundige bron as die gewone geskiedenis. Montague (1997:53) som dit goed op: "The events of history were more for formation than for information." (Kursivering Montague.)

\subsection{Bybelverstaan gedurende die Renaissance en daarna}

Gedurende die eerste helfte van die vyftiende eeu het stemme soos dié van Thomas à Kempis (ca. 1380-1471) begin opgaan om terug te keer na 'n eenvoudige, oftewel letterlike verstaan van die teks, gestroop van ingewikkelde allegoriese spekulasie (Jasper, 2004:51). 'n Ongekende verandering in die tydgees, letterlik 'n "hergeboorte", het verdere impetus aan hierdie ontwikkeling gee. Dit het terselfdertyd nuwe moontlikhede vir die verstaan van die Bybel geopen.

Die Renaissance was niks minder as 'n kulturele revolusie nie. Volgens Yarchin (2004:171) verwys dit na 'n breuk met vorige dominante kulturele tradisies weens 'n komplekse reeks veranderende politiese, tegnologiese en ekonomiese omstandighede. Die slagspreuk van die Renaissance-humaniste was: ad fontes - "na die bronne". In die studieveld van die menswetenskappe het die besef deurgedring dat ouer bronne die sleutel tot die verstaan van ouer kulture en kultuurgoedere dra. Dit het onder andere daartoe gelei dat die Hervormers, onder die invloed van hierdie gedagtegang, ondersoek 
ingestel het na daardie bronne wat die Bybel ten grondslag lê,17 naamlik die Hebreeuse en Griekse tekste van onderskeidelik die Ou- en Nuwe Testamente (Oeming, 2006:32). Hierdie benadering het ook 'n bepalende invloed gehad op die wyse waarop die Bybel verstaan is. Die hervormers se fokus op sola Scriptura (die Skrif alleen) het ingehou dat die Bybel in die letterlike betekenis daarvan duidelik was en nie bykomende (kerklike) allegoriese interpretasie benodig het nie. Die letterlike betekenis omvat ook die (hoër) teologiese betekenis wat gedurende die vroeër era deur die allegoriese/morele/anagogiese vorm van verstaan ontsluit moes word. Die monopolie wat die kerk op die verstaan en betekenis van die Bybel uitgeoefen het, het hierdeur in gedrang gekom.

'n Welbekende Ou-Testamentikus John Barton (1998:16) wys daarop dat die Reformasie juis die impetus vir die geweldige ontwikkeling op die gebied van die verstaan van die Bybel gedurende die afgelope ongeveer 500 jaar was. Die Reformasie het die gesag van die Skrif bo die gesag van die kerk en kerklike tradisie gestel, maar die reformatore het nie die gesag van die Skrif betwyfel soos wat die geval was tydens die verdere ontwikkeling, veral na die Verligting nie.18 Hierdie klem op die Skrif alleen het egter daarmee saam 'n nuwe probleem gebring, naamlik die verskillende wyses waarop die Bybel verstaan is. In die vorige era het die kerk as gesagstruktuur grootliks die verstaan van die Bybel bepaal - nou het daardie homogeniteit plek gemaak vir diversiteit. Die geskiedenis van die Protestantse tradisie wys hoe diversiteit gelei het tot verskillende vorms waarbinne die sentrale gedagtes van die hervormers op verskillende maniere uitdrukking gevind het.

Ter wille van volledigheid is dit nodig om ook enkele lyne te trek met betrekking tot die verdere geskiedenis van Bybelverklaring. Die terugkeer na die bestudering van die (oorspronklike) teks(te) van die Bybel om sodoende betekenis te bepaal, tesame met die ontwikkeling wat die nuwe ondersoekende tydsgees meegebring het in vakgebiede soos taalkunde en geskiedenis, het Bybelverklaring

17 Die Latynse vertaling van die Bybel was gedurende hierdie era die amptelik erkende Bybel. Die Hervorming het baie daartoe bygedra dat die Bybel uit die oorspronklike tale ook in die omgangstale van daardie tyd vertaal is.

18 Barton (1998:16) maak 'n goeie saak daarvoor uit dat gelowiges volgens die beginsels van die Reformasie die reg het om te vra of die Bybel werklik beteken wat die kerk sê dit beteken. Om hierdie betekenis te bepaal, is gebruik gemaak van algemene, aanvaarbare, rasionele beginsels. Hierdeur is 'n nuwe era in die Bybelwetenskap ingelui. 
spoedig in nuwe rigtings gestuur. Die tale waarin die Ou Testament geskryf is (Hebreeus en Aramees), is binne 'n groter geheel (Semitiese Tale) geklassifiseer en vergelykende studies sou nuwe insigte met betrekking tot die betekenis van die teks blootlê. Antieke geskiedenis is ook met ander oë bejeën en meer wetenskaplike metodes het ontwikkel waarop geskiedkundige bronne met mekaar vergelyk is om ' $n$ beter beeld van historiese gebeure te verkry. Antieke kulture en kultuurprodukte kon ook met mekaar vergelyk word (vgl. die ontwikkeling van Argeologie as vakwetenskap), en ooreenkomste en verskille is waargeneem. Algaande het die (historiese) besef ontstaan dat die Bybel uit 'n totaal vreemde sosio-kulturele konteks kom, en dat die letterlike (historiese) betekenis van die teks ingebed is in 'n groter taalkundige, historiese en religieuse geheel. Dit is juis hierdie aspekte waarop die fokus tydens die verdere ontwikkeling van Bybelinterpretasie geval het.

Hierdie verdere ontwikkeling word gewoonlik in drie fases beskryf, naamlik histories-, literêr- en lesergefokus. ${ }^{19}$ Hierdie drie fases verteenwoordig die klemverskuiwings wat in verwante vakwetenskappe tydens hierdie tydperk voorgekom het. Eie aan die aard van die reformatoriese benadering, moes hierdie nuwe beklemtonings binne die sentrale ondersoek na wat die Bybel sê - sola Scriptura - verreken word. Indien nuwe modelle van ondersoek nuwe verstaansmoontlikhede open, moet daardie modelle in die gees van 'n voortdurende reformasie (semper reformanda) ondersoek word. Die geweldige kennis-ontploffing gedurende die twintigste eeu, maar veral na die Tweede Wêreldoorlog, het daartoe gelei dat nuwe verklaringsmodelle mekaar te vinnig opgevolg het. Selfs in reformatoriese kringe het navorsers begin om hulle agter die dogmatiese skuilings van amptelike kerklike uitsprake of tradisionele interpretasies te verskans. Ironies genoeg was dít juis waarvan die Reformasie gelowiges wou bevry.

19 Chronologies kan hierdie ontwikkeling soos volg weergegee word: die historiese benadering het die negentiende en vroeg-twintigste eeu grootliks oorheers, terwyl 'n meer literêre benadering (n.a.v. ontwikkelings in die algemene literatuurwetenskap) gedurende die tweede helfte van die twintigste eeu 'n invloed op die Bybelwetenskappe begin uitoefen het. 'n Lesergefokusde benadering het gedurende die laaste kwart van die twintigste eeu prominensie in die Bybelwetenskappe begin kry. Contra hierdie konsensus wys Barton (1996:20-23) daarop dat die benaming "histories" vir dit wat in die Bybelwetenskappe gedoen is tot en met die middel van die twintigste eeu, in wese 'n literêre benadering verteenwoordig. 
'n Verdere bespreking van die ontwikkeling binne die histories-, literêr- en lesergefokusde benaderings val buite die grense van hierdie artikel, maar is elders goed gedokumenteer (vgl. Le Roux, 1993). Hierdie oorsig het ten doel om die grammaties-historiese metode wat hier onder die loep kom, teen 'n bepaalde agtergrond te beskou. Hierdie oorsig wek die idee dat 'n figuurlike verstaan van die teks tot en met die Renaissance, Bybelinterpretasie oorheers het. Indien 'n mens die pad van die grammaties-historiese metode verder terug wil neem as die Reformasie, raak die getuienis min en moet sommige van die bestaande getuienis bloot verontagsaam word. Pogings soos dié van Scheffler (1991:65) om 'n meer direkte verband met die Antiochiese tradisie bloot te lê, maak nie genoegsaam erns met die verskillende sienings van "histories" wat onderskeidelik voor en na die Middeleeue gangbaar was nie. Vervolgens word nagegaan wat die grammaties-historiese metode behels en hoe dit by hierdie verhaal van Bybelinterpretasie inpas.

\section{Grammaties-historiese eksegese}

\subsection{Verskuiwings binne evangeliese kontekste}

Binne die GKSA word die grammaties-historiese metode in sowel kerklike as akademiese kringe hoog aangeslaan, en word uitsluitlik hierdie metode in die verklaring van die Bybel gebruik. In hierdie afdeling word geargumenteer dat hierdie metode binne akademiese konteks nie wyd erkenning geniet nie, en waar dit wel gebruik word, dit nie duidelik gedefinieer word nie. Verder word daarop gewys dat die metode nie genoegsaam rekening hou met al die aspekte (nl. histories-, literêr- en lesergefokus) wat in die leesproses ter sprake is nie. 20

Alhoewel 'n mens die begrip grammaties-historiese eksegese veral raaklees in teologies behoudende werke wat oor Bybelinterpretasie handel (vgl. Enns, 2005:131-133; 158-160), bied min van daardie werke 'n goeie uiteensetting van die begrip. Die standaard ver-

20 Uit eie bodem het hierdie sake in die konteks van multidimensionele benaderings tot die teks reeds uitvoerige aandag ontvang (vgl. Jonker, 1996; Groenewald, 2003). Die fokus val nie in hierdie bespreking op daardie benaderings nie, maar eerder op bepaalde probleme met die grammatieshistoriese metode. 
wysingsbronne in die veld van Bybelinterpretasie maak nie van hierdie metode melding nie.21

'n Omvattende bespreking van die begrip word deur Scheffler (1991) gegee, maar hyself staan nie binne die tradisie waarin hierdie metode uitsluitlik gebruik word nie. Hy verwys onder andere na die volgende sake: alternatiewe benamings wat histories-filologies of histories-letterlik insluit. Die historiese verstaan beteken dat die teks na werklike gebeure verwys en dus as geskiedskrywing beskou word; grammatiese verstaan behels dat klem geplaas word op kennis van die grammatika van die grondtale vir die verstaan van die teks (Scheffler, 1991:55-56). Hierdie uiteensetting van Scheffler word deur die samevatting van Kaiser en Silva (1994:19) ondersteun: "grammatico-historical indicates ... that this analysis must pay attention both to the language in which the original text was written and to the specific cultural context that gave rise to the text". Verder word besprekings van die grammaties-historiese metode gewoonlik gekenmerk deur die kontrastering daarvan met die histories-kritiese benadering (Scheffler, 1991:67; Kaiser \& Silva, 1994:19, 235).

Resente literatuur vanuit evangeliese kringe vertoon egter 'n meer genuanseerde siening ten opsigte van historiese kritiek. Long (1997:92-102) argumenteer byvoorbeeld dat indien 'n navorser vanuit teïstiese vooronderstellings werk, daar niks is wat verhoed dat histories-krities met die teks omgegaan word nie - trouens die teks vereis dit (Long, 1997:95). Nog meer radikaal merk Burnett (2005: 292) in 'n meer behoudende publikasie op:

Historical criticism can help not only to liberate readers from layers of false presuppositions and conceptions laid upon the text by the history of interpretation and tradition. It can also help to shatter the false images 22 the inappropriate conjectures and unwarranted constructions modern (and even postmodern) interpreters often bring to the Bible. It can serve to alert readers to the often utterly foreign nature of biblical texts and their various antecedents ... if genuinely critical, it can neither

21 Vergelyk Coggins en Houlden (1992), Hayes (1999) en VanHoozer (2005). Verder word die grammaties-historiese metode nie in 'n uitgebreide dokument vermeld waarin die Rooms-Katolieke Kerk besin oor metodes van Bybelinterpretasie nie (vgl. Pous Johannes Paulus II, 1994).

22 Hierdie idee herinner aan die opmerking van Mudge (1980:18) in sy oorsig oor die bydrae van Paul Ricoeur tot Bybelverklaring: "We have no alternative today to working through criticism toward a second naïveté because the first naïveté available to us in our culture is so deeply idolatrous." 
undermine nor establish faith, but can assist interpreters in being self-critical and therefore modest about their own results.

Burnett vervolg deur op soortgelyke wyse as Enns (2005), die noodsaak vir histories-kritiese omgang met die teks juis te soek in die feit dat die Bybel ook 'n menslike boek is. Enns versterk sy argument deur sy oproep in verband te bring met die twee nature van Christus (vgl. die titel van sy werk). Hier onder sal ek daarna verwys dat die menslike natuur van Christus, in die persoon van Jesus, 'n verdere belangrike perspektief met betrekking tot Bybelinterpretasie open.

Nadat kennis geneem is van 'n verruiming binne die evangeliese konteks (met betrekking tot die gebruik van histories-kritiese metodes), word daarop gelet hoe die spanning wat daardeur geskep word in latere publikasies manifesteer. Tolar (2002:21) neem as vertrekpunt dat die grammaties-historiese metode die sine quo non vir die geldige verstaan van die Woord van God is. Ondanks die inklusiewe titel van die werk waarin sy bydrae verskyn, Biblical hermeneutics: a comprehensive introduction to interpreting Scripture, word daarin hoofsaaklik polemies met "ander" (historiese en literêre) metodes van Bybelinterpretasie omgegaan (vgl. Johnson, 2002:131146). Die positiewe opmerkings wat Johnson wel oor moderne historiese en literêre metodes maak, is nie in Tolar se bydrae oor die grammaties-historiese metode verdiskonteer nie. ${ }^{23}$ Geen evaluering van die grammaties-historiese metode word aangebied nie. Wanneer hierdie metode bespreek word, word ondersoek ingestel na wat die "grammatiese beginsel" en die "historiese beginsel" genoem word (Tolar, 2002:21, 29). Aspekte wat onder eersgenoemde aandag kry, is van 'n taalkundige aard, byvoorbeeld woorde en sinne, figuurlike taalgebruik en enkele opmerkings aangaande spesiale sake soos poësie, simboliek en tipologie. Onder historiese word slegs aspekte soos sleutelpersone (outeur, oorspronklike lesers en hoorders, asook ander bronne), gemeenskap, geografie en topografie vermeld.

In die hantering van hierdie twee beginsels word nie tot die kern daarvan binne 'n akademiese konteks deurgedring nie. Wat die grammatiese betref, sal hier onder aangetoon word dat hierdie begrip, soos deur die reformatore gebruik, nie in die eerste plek 'n aanduiding van taalkundige aspekte gee nie. Dit gee eerder 'n aan-

23 Tolar gee ook nie erkenning aan die insigte vanuit moderne literêre en historiese oorde wat deur Freeman (2002:387-397) in dieselfde publikasie uitgelig word nie. 
duiding van die wyse waarop met die taal tydens interpretasie omgegaan word. Enige persoon wat met historiese studie vertroud is, sal besef dat die aspekte wat onder die historiese beginsel bespreek word (veral ten opsigte van antieke tekste), naïef voorkom. Binne die grammaties-historiese metode word hierdie aspekte dikwels uit die teks afgelei (Scheffler, 1991:19) sonder verdere grondige historiese ondersoek. In plaas daarvan om 'n werklike historiese (diakroniese) metode te wees; versand die grammaties-historiese metode in 'n soort literêre (sinkroniese) metode waarin die teks as sodanig sentraal staan, los van enige historiese oorwegings daarbuite. Alhoewel daar dus binne evangeliese kringe waardering bestaan vir die bydrae van meerdere metodes, kom bitter min daarvan tereg in die toepassing van die grammaties-historiese metode.

Clines (1998) gee in sy verklaring van "histories-grammatiese" eksegese 24 die volgende definisie: "to interpret any passage according to the natural sense of the words ('grammatical') and according to the probable meaning of the author in his own time ('historical')". Hy voer die ontstaan van hierdie metode terug na die Reformasie waar dit as teenvoeter vir die "arbitrary or fanciful [allegorical] interpretations" van die voor-Reformasie-era moes dien. Hieruit is dit duidelik dat hy minder van die grammatiese aspek maak as Tolar, wat allerlei taalkundige sake daaraan koppel. Dat Clines se definisie ook verskil wat betref die historiese aspek, is goed waarneembaar uit sy toepassing daarvan in die verklaring van die meervoud in Genesis 1:26 ("Laat ons mense maak") en die verwysing na God se seun in Psalm 2:7.25

Voorts sal sy siening van redaksiegeskiedenis as onderdeel van histories-grammatiese eksegese, nie geredelik erken word nie. Clines (1998:30) merk in hierdie verband op: "A careful reader of this history [Joshua-2 Kings] will not imagine that it was written simply to record the past, but will find in it clues to the author's intention, purpose or bias." Uit wat volg, sal blyk dat grammaties-

24 Clines se ordening van die begrippe val op, naamlik histories-grammaties in plaas van grammaties-histories. Uit sy definisie is dit duidelik dat hy, wat die grammatiese aspek betref, nie uitgebreide taalkundige verklarings impliseer nie, maar bloot na die gewone (letterlike) betekenis van die woorde verwys.

25 In die eerste geval verwerp Clines (1998:27) die idee dat "ons" na die Drieeenheid verwys. Wat Psalm 2 betref, voer hy aan dat die navolging van die historiese-grammatiese metode dit onmoontlik maak om Christus hier in te lees en dat die verwysing na die koning as seun van God is. 
historiese eksegese in teenstelling hiermee 'n baie letterlike verstaan van die teks as vertrekpunt neem. ${ }^{26}$

Uit die bespreking blyk dat die grammaties-historiese metode nie altyd dieselfde betekenis dra nie. ${ }^{27}$ Verder is daarop gewys dat hierdie metode in sommige opsigte teruggevoer kan word na die Reformasie toe 'n letterlike verstaan van die oorspronklike teks onder die hervormers voorrang gekry het bo 'n figuurlike interpretasie daarvan.

\subsection{Reformatoriese wortels?}

Op hierdie punt moet die vraag gevra word tot watter mate die grammaties-historiese benadering getrou bly aan die reformatoriese tradisie soos dit na onder andere Calvyn teruggevoer kan word.28 Hans Frei (1974:18-37) toon in sy gesaghebbende studie oor die agtiende- en negentiende-eeuse hermeneutiek aan dat 'n onderskeid tussen die letterlike (grammatiese) en die historiese vir die reformatore nie bestaan het nie. Luther gebruik die begrippe grammaties of histories wanneer hy "letterlik" bedoel (Frei, 1974:19). So ook Calvyn: "Calvin simply did not separate the literal ... meaning of a text from its historical reference" (Frei, 1974:23).

Die behoudende Ou-Testamentikus Walter Kaiser (1981:87-89) koppel die verwysing na grammaties-historiese eksegese aan die vroeë negentiende-eeuse werk van Keil, waarvan die oorspronklike Duitse

26 Clines staan weliswaar krities teenoor die vermoë van die histories-kritiese metode om 'n bydrae tot Bybelinterpretasie te lewer. Gesien in die lig daarvan dat hy verkies om vanuit 'n literêre benadering die teks te verklaar, is dit nie verrassend nie. Ek dink egter dat hy die bydrae van historiese kritiek onderwaardeer. As voorbeeld kan verwys word na Collins (1993) se uitmuntende kommentaar oor die boek Daniël vanuit 'n konsekwente historieskritiese hoek. Hierdie werk lewer 'n besliste bydrae tot die verstaan van die boek Daniël.

27 Dieselfde geld ook vir die benaming histories-kritiese metode. Dit is ironies dat Wellhausen (1885) in sy Prolegomena persone wat probeer om die tradisionele (openbaringshistoriese) oorlewering van die Pentateug te beskryf, aan die hand van die bron-volgorde $\mathrm{P}, \mathrm{J}$, en $\mathrm{D}$, beskuldigend tipeer asof hulle tot die "socalled historico-critical school" behoort (Wellhausen, hfst. 6, III, 2). Dit is duidelik dat historiese kritiek selfs nog in die laat-negentiende eeu in sommige kringe 'n veel ander betekenis gehad het as wat dit vandag het!

28 Calvyn is sekerlik die eksponent par excellence van hierdie benadering in sy "oorspronklike" vorm. 'n Goeie voorbeeld is waar hy "letterlike" gronde aanvoer waarom Genesis 3:15 nie na Christus kan verwys nie. Volgens hom lees die voorstanders van so 'n interpretasie bloot veel meer in die teks in as wat daar staan (Calvyn, 1984:170-171). 
titel29 (1810) hierdie benaming weerspieël. Kaiser (1981:88) wys ook daarop dat die grammatiese aspek nie soseer na taalkundige sake verwys nie, maar eerder na "the simple, direct, plain, ordinary, and literal sense of the phrases, clauses, and sentences". Kaiser (1981:88) neem egter nie genoegsaam daarvan kennis dat die onderskeid tussen grammatiese en historiese betekenis wat insluit "a careful consideration of the time and circumstances in which the author wrote", nie vir die reformatore bestaan het nie. Soos reeds daarop gewys, het die historiese aspek vir die reformatore met die letterlike (grammatiese) betekenis van die teks saamgeval. Hierdie onderskeid is eers later gemaak en het, volgens Frei (1974), aanleiding gee tot die ontwikkeling van die Bybelse Teologie-benadering enersyds, en andersyds die histories-kritiese benadering.

Wanneer grammaties (letterlik) en histories van mekaar geskei word, word in wese wegbeweeg van daardie interpretasievorm wat tydens die Reformasie sy beslag gekry het. Hierdie benadering wou juis 'n alternatief daarstel vir die komplekse vierledige vorm van interpretasie wat die uitsluitlike alleenreg van die kerk was. Die Woord van God soos dit geskryf staan (sola Scriptura), sonder enige verdere ondersoek na 'n diepere, eintlike of toegepaste betekenis, was die studie-objek van die Reformatore. Die betekenis van die teks is bloot wat in die teks geskryf staan. Meer indringende vrae na kultuurhistoriese en sosiologiese agtergrond het eers later deel geword van die diskussie, maar steeds in 'n poging om te bepaal "wat sê die Bybel". Frei (1974:78) toon aan hoe hierdie ontwikkeling begin by Anthony Collins in die vroeë agtiende eeu, wanneer hy betekenis losmaak van "dit wat daar staan" en dit koppel aan 'n referent buite die teks, naamlik die bedoeling van die outeur. Hiermee is die eerste tree gegee op die pad wat uiteindelik op historiese kritiek uitgeloop het. Die teks dra nie meer (soos by die Reformatore) betekenis in sigself nie, maar eksterne faktore speel op daardie betekenis in. $\mathbf{3 0}$

29 "Lehrbuch der Hermeneutik des neuen Testamentes nach Grundsätzen der grammatisch-historischen Interpretation." Die latere Latynse vertaling van hierdie werk (Elementa hermeneuticis Novi Testamenti - 1811) verwys nie eksplisiet daarna in die titel nie.

30 Frei (1974) bied 'n boeiende bespreking van die res van hierdie ontwikkeling, maar doen terselfdertyd aan die hand dat teruggekeer word na die vertelling in die teks as primêre toespitsing van interpretasie. Hierdie teksimmanente benadering dra swaar aan filosofiese vrae met betrekking tot referensie en die geslotenheid van die wêreld van die teks. Antwoorde op hierdie vrae is wel reeds aangebied (vgl. Comstock, 1986). 


\section{3 'n Omvattender benadering}

Die bespreking het tot dusver gefokus op kritiek dat die historiese, in grammaties-histories, grootliks tot die wêreld in die teks beperk word. Voorts is aangetoon dat die grammatiese aspek eerder na letterlik as na taalkundig verwys. 31 Die laaste aspek van die leesproses wat binne enige omvattende benadering tot Bybelinterpretasie verdiskonteer moet word, het betrekking op die rol van die leser. Die volle konsekwensie van die rol van vooronderstellings in die verstaan van tekste is nog nie binne teologiese kringe verdiskonteer nie. Die moderne literatuurwetenskap het die rol van die leser in die leesproses op teoretiese vaste grond geplaas. Daar is ook al aangetoon hoe hierdie teorie getoets kan word met betrekking tot die verstaan van die Bybel wat die rol van die vrou in die kerk betref (Van Deventer, 2005b).

Snyman (2007) het die hele saak aangaande die rol van die leser in die leesproses, en die verantwoordelikheid wat dit meebring in diepte bespreek. In navolging van Levinas betoog hy dat die leser nie net bewus moet wees van sy/haar eie verwysingsraamwerk en die invloed wat dit op die leesproses het nie, maar ook bedag moet wees op die gevolge wat die interpretasie vir ander inhou. Die gereformeerde hermeneutiek in die algemeen en die grammaties-historiese metode in die besonder, moet nog aan hierdie subjektiewe aspek aandag gee. Hierdie element bestaan binne alle tradisies, maar word dikwels deur 'n (onbevraagtekenbare?) konfessionele raamwerk beheers. ${ }^{32}$ Tans gee die konfessionele verstaan die toon aan en word kreatiwiteit binne die tradisie onderdruk. ${ }^{33}$

Hoe sou die pad vorentoe lyk vir 'n hermeneutiese benadering wat meer omvattend is as die huidige grammaties-historiese metode?

31 Niks verhoed 'n navorsingsgemeenskap om "grammaties" aan "taalkundig" te koppel nie, maar dan nie met 'n beroep op die reformatore nie.

32 Die reformatoriese tradisie stel juis die konfessie sekondêr tot die Skrif. Ongelukkig is ontwikkelings in Skrifverstaan nog nie binne die premoderne konfessionele raamwerk verdiskonteer nie en dogma funksioneer op 'n soortgelyke wyse as in daardie tradisie waarvandaan die reformatore weggebreek het. Dit is ironies dat juis die Rooms-Katolieke Kerk 'n dokument die lig laat sien het waarin meerdere interpretasiemetodes aanbeveel word (vgl. Pous Johannes Paulus II, 1994).

33 Buite die Gereformeerde kring is wel tekens dat die kreatiwiteit wat die ontwikkeling in die wetenskap van verstaan binne die reformatoriese tradisie geopen het, besig is om na ander dele van die teologiese landskap deur te vloei (vgl. op meer populêre vlak Du Toit (2000) en Van Niekerk (2005)). 
Eerstens moet 'n mens steeds aan die reformatoriese tradisie met sy ononderhandelbare klem op sola Scriptura getrou bly. Dit impliseer wel verstellings wat betref die verwoording en verantwoording van geloof in 'n hedendaagse konteks. In hierdie opsig sal wat Bybelinterpretasie betref, aansluiting by die Bybelse Teologiebeweging gevind kan word. In daardie tradisie word religieuse en historiese verstaan bymekaar gehou.

For biblical interpretation without biblical theology is (theologically speaking) empty; and biblical theology without biblical interpretation is (hermeneutically speaking) naive ... On the one hand, the books of the Bible are historical documents; on the other hand, they are also the church's Scriptures. (Vanhoozer, 2000:52.)

Wat die historiese dimensie van verstaan betref, word 'n fokus op die teks bepleit, maar dan langs die weg soos deur Barton (2007: 186) voorgestel: "really listening to what the text is saying, before making up one's mind about its claims". Dit beteken dat baie van die resultate van die historiese kritiek wel verdiskonteer moet word, veral waar dit antwoorde bied op vrae wat deur 'n teksgefokusde lees opgeroep is (bv. die twee skeppingsverhale in Genesis, of die datering van die boek Daniël). In hierdie opsig sal die resultate van die grammaties-historiese lees van die Bybel, spesifiek soos in "Openbaringsgeskiedenis" gemanifesteer (vgl. Van der Walt, 2007), 'n grens aan die een kant van die spektrum vorm. Word hierdie grens oorgesteek, is die kanse goed om in 'n vorm van biblisisme te verval. Botha (2009) se onlangse bydrae oor die waarde van die historiese-Jesusnavorsing, bied, myns insiens, 'n gepaste grens vir die ander kant van die spektrum. Indien die grens na daardie kant oorgesteek word, verval teologie in 'n vorm van rasionalisme. Indien hierdie grense vir sommige navorsers te ver uitmekaar lê, moet ernstige vrae gestel word oor ons siening van die akademiese konteks waarbinne hierdie werk gedoen word. Die verruiming van interpretasiemodelle staan baie nader aan die reformatoriese tradisie as wat die verskansing van 'n vorm van fundamentalisme daaraan is.

Die literêre dimensie van verstaan impliseer dat die teks "in all its literary integrity as a complex written communication" (Vanhoozer, 2000:58) gesien word. Die verstaan van 'n teks veronderstel dus meer as die weergee van werkwoordvervoegings, maar impliseer 'n begrip van die wyse waarop spraakhandelinge in tekste manifesteer.

Laastens kan die leserdimensie by verstaan nie geïgnoreer word deur dit bloot binne 'n dogmatiese tradisie te kerker nie. Die verant- 
woordelikheid wat lees meebring, mag nie ontken word nie. Die maatstaf hiervoor kan in die teks self gevind word. In hierdie verband moet die resultate van ondersoeke na die historiese Jesus ontgin word. Hier word spesifiek verwys na die werk deur Van Aarde (2001). Alhoewel die Jesus wat ons deur Van Aarde ontmoet menige ekonomies- en polities-bevoordeelde persone ongemaklik op hulle stoele sal laat rondskuif, bied dit terselfdertyd 'n goeie barometer om te bepaal tot watter mate die leser sy/haar etieke verantwoordelikheid met die lees van die teks nagekom het.

Tradisioneel word gereformeerde hermeneutiek eerder aan die soteriologiese Christus gekoppel. Dit is 'n aspek wat binne die Christelike geloofstradisie nie kan wegval nie. Wat voorgestel word, is dat dit met die historiese Jesus aangevul word, in besonder om daarmee ons interpretasies te kontroleer met betrekking tot die gevolge wat dit vir ander inhou. Aan persone wat uitsluitlik met die soteriologiese Christus as verwysingspunt vir interpretasie wil werk, behoort die fyn uitgewerkte leer oor die twee nature van Jesus Christus genoegsame oortuigingskrag te bied vir die werkbaarheid en noodsaak van hierdie moontlikheid. Die enigma wat in hierdie Persoon opgesluit is en wat ook vanuit Gereformeerde hoek histories ondersoek moet word, kan myns insiens 'n goeie maatstaf wees vir interpretasies en die invloed daarvan op ander teoloë. 34

\section{Slot}

In 'n poging om voorstelle te maak vir die ontwikkeling van grammaties-historiese eksegese tot ' $n$ meer omvattender interpretasiemodel, het hierdie artikel by ' $n$ interpretasie in die Bybel self begin. Daar is in breë trekke op die geskiedenis van interpretasie gelet en hoe verskillende verklaringtradisies ontwikkel het. Die slotsom wat bereik is, is dat indien die grammaties-historiese metode as produk van die reformatoriese teologie wil voortbestaan, aanpassings daaraan gemaak sal moet word. Hierdie aanpassings kan vanuit die Bybelse Teologietradisie steeds die dogmatiese en daarmee saam soteriologiese aspekte van Bybelverklaring soos vergestalt in Jesus Christus verskans. Terselfdertyd kan verklarings verdiep en die praktiese konsekwensies daarvan getoets word deur konsekwent histories met die teks om te gaan. In hierdie proses kan die lewe en werk van Jesus van Nasaret as maatstaf en kontrole dien.

34 Die resultate van die historiese Jesusnavorsing word reeds binne die Praktiese Teologie verdiskonteer (vgl. Pieterse, 2009). 


\section{Geraadpleegde bronnne}

AICHELE, G., MISCALL, P. \& WALSH, R. 2009. An elephant in the room: historical critical and postmodern interpretations of the Bible. Journal of biblical literature, 128(2):383-404.

AICHELE, G. \& PHILLIPS, G.A., eds. 1995. Intertextuality and the Bible. Atlanta: Scholars.

ATHAS, G. 2009. In search of the seventy "weeks" of Daniel 9. Journal of Hebrew Scriptures. http://www.arts.ualberta.ca/JHS/Articles/article_104. pdf Date of access: 7 Feb. 2009.

BARTON, J. 1996. Reading the Old Testament: method in biblical study. Revised and enlarged. Louisville: Westminster.

BARTON, J. 1997. Holy writings, sacred text: the canon in early Christianity. Louisville: Westminster.

BARTON, J. 1998. Historical-critical approaches. (In Barton, J., ed. The Cambridge companion to biblical interpretation. Cambridge: Cambridge University Press. p. 9-20.)

BARTON, J. 2007. The nature of biblical criticism. Louisville: Westminster.

BIBLE AND CULTURE COLLECTIVE. 1995. The postmodern Bible. New Haven: Yale University Press.

BOTHA, P.J.J. 2009. Historical Jesus research and relevance in South Africa. HTS theological studies, 65(1):11. DOI: 10.4102/hts.v65i1.154.

BRAY, G. 1996. Biblical interpretation: past and present. Downers Grove: InterVarsity.

BURNETT, R.E. 2005. Historical criticism. (In Vanhoozer, K.J., ed. Dictionary for the Theological Interpretation of the Bible. Grand Rapids: Baker. p. 290-293.)

CALVIN, J. 1984. Commentaries on the first book of Moses called Genesis. Grand Rapids: Baker.

CLINES, D.J.A. 1998. On the way to the postmodern: Old Testament essays, 1967-1988. Sheffield: Sheffield Academic Press.

COGGINS, R.J. \& HOULDEN, J.L. 1992. A Dictionary of Biblical Interpretation. London: SCM.

COLLINS, J.J. 1993. Daniel (Hermeneia). Minneapolis: Fortress.

COMSTOCK, G. 1986. Truth or meaning: Ricoeur vs. Frei on Biblical narrative. The journal of religion, 66(2):117-140.

DU TOIT, B. 2000. God? Geloof in 'n postmoderne tyd. Bloemfontein: CLF.

ENNS, P. 2005. Inspiration and incarnation: evangelicals and the problem of the Old Testament. Grand Rapids: Baker.

FEWELL, D.N., ed. 1992. Reading between text: intertextuality and the Hebrew Bible. Louisville: Westminster.

FLINT, P.W., ed. 2001. The Bible at Qumran: text shape and interpretation. Grand Rapids: Eerdmans.

FREEMAN, H. 2002. Biblical criticism and biblical preaching. (In Corley, B., Lemke, S.W. \& Lovejoy, G.I., eds. Biblical hermeneutics: a comprehensive introduction to interpreting Scripture. 2nd ed. Nashville: Broadman \& Holman. p. 387-397.)

FREI, H.W. 1974. The eclipse of biblical narrative: a study in eighteenth and nineteenth century hermeneutics. New Haven: Yale University Press.

GROENEWALD, A. 2003. Psalm 69: its structure, redaction and composition. Münster: Lit-Verlag. 
GUTHRIE, D. 1977. Questions of introduction. (In Marshall, I.H., ed. New Testament interpretation: essays in principles and methods. Exeter: Paternoster. p. 105-116.)

HAYES, J.H., ed. 1999. Dictionary of Biblical Interpretation. Nashville: Abingdon.

JASPER, D. 2004. A short introduction to hermeneutics. Louisville: Westminster.

JOHNSON, R. 2002. Modern Old Testament interpretation. (In Corley, B., Lemke, S.W. \& Lovejoy, G.I., eds. Biblical hermeneutics: a comprehensive introduction to interpreting Scripture. 2nd ed. Nashville: Broadman \& Holman. p. 131-146.)

JONKER, L.C. 1996. Exclusivity and variety: perspectives on multidimensional exegesis. Kampen: Kok. (Contributions to Biblical Exegesis and Theology 19.)

KAISER, W.C. 1981. Toward an exegetical theology: biblical exegesis for preaching and teaching. Grand Rapids: Baker.

KAISER, W.C. \& SILVA, M. 1994. An introduction to biblical hermeneutics: the search for meaning. Grand Rapids: Zondervan.

LE ROUX, J.H. 1993. A story of two ways: thirty years of Old Testament scholarship in South Africa. Pretoria: Verba Vitae.

LONG, V.P. 1997. Old Testament history: a hermeneutical perspective. (In VanGemeren, W.A., ed. New International Dictionary of Old Testament Theology and Exegesis. Vol. 1. Grand Rapids: Zondervan. p. 86-102.)

MCDONALD, L.M. 2007. The biblical canon: its origin, transmission, and authority. Peabody: Hendrickson.

MOI, T., ed. 1986. The Kristeva reader. Oxford: Blackwell.

MONTAGUE, G.T. 1997. Understanding the Bible: a basic introduction to biblical interpretation. New York: Paulist.

MUDGE, L.S. 1980. Introduction. (In Ricoeur, P. Essays in biblical interpretation. Ed. by L.S. Mudge. Philadelphia: Fortress. p. 3-30.)

OEMING, M. 2006. Contemporary biblical hermeneutics: an introduction. Trans. by J.F. Vette. Aldershot: Ashgate.

PIETERSE, H.J.C. 2009. Prediking oor die koninkryk van God: 'n uitdaging in 'n nuwe konteks van armoede. HTS teologiese studies, 65(1):6. DOI: 10.4102/hts.v65i1.106.

POSTMODERN BIBLE see BIBLE AND CULTURE COLLECTIVE

POUS JOHANNES PAULUS II. 1994. The interpretation of the Bible in the church. Origins, 23(29):497-524.

REVENTLOW, H.G. 2009a. History of biblical interpretation: from the Old Testament to Origen. Vol. 1. Williston: Society of Biblical Literature (SBL).

REVENTLOW, H.G. 2009b. History of biblical interpretation: from the Old Testament to Origen. Vol. 2. Williston: Society of Biblical Literature (SBL).

SCHEFFLER, E. 1991. Waarna verwys die Woord? Histories-grammatiese eksegese. (In Bosman, H.L., Gous, I.P.G. \& Spangenberg, I.J.J. Purper en flenterlap: rykdom en armoede in die Ou Testament. Pretoria: Van Schaik. p. 55-69.)

SNYMAN, G. 2007. Om die Bybel anders te lees: 'n etiek van Bybellees. Pretoria: Griffel.

SNYMAN, S.D. 2008. Wanneer 'n teks tekste aanhaal: Maleagi 1:6-14 as voorbeeld. Acta theologica, 28(2):86-103. 
TOLAR, W.B. 2002. The grammatical-historical method. (In Corley, B., Lemke, S.W. \& Lovejoy, G.I., eds. Biblical hermeneutics: a comprehensive introduction to interpreting Scripture. 2nd ed. Nashville: B\&H. p. 21-38.)

VAN AARDE, A. 2001. Fatherless in Galilee: Jesus as Child of God. Harrisburg: Trinity.

VAN DER WALT, T. 2007. Die Messias het gekom! 'n Gids in die Evangelies vir toegewyde Bybel-studente. Potchefstroom: Potchefstroomse Teologiese Publikasies.

VAN DEVENTER, H.J.M. 2005a. Pardon my paradigm: on the paradigmatic nature of methods and paradigm changes in biblical studies. Old Testament essays, 18(3):847-862.

VAN DEVENTER, H.J.M. 2005b. Why minds are changed: an inquiry into the decisions by the Gereformeerde Kerke in Suid-Afrika (GKSA) on the role of women in the church. Koers, 70(4):685-704.

VAN NIEKERK, A. 2005. Geloof sonder sekerhede: besinning vir eietydse gelowiges. Wellington: Lux Verbi.BM.

VAN SETERS, J. 2009. A response to G. Aichelle, P. Micall and R. Walch "An elephant in the room: historical critical and postmodern interpretations of the Bible". Journal of Hebrew Scriptures. http://www.arts.ualberta. ca/JHS/Articles/article_128.pdf Date of access: 8 Jan. 2010.

VANHOOZER, K.J. 2000. Exegesis and hermeneutics. (In Rosner, B.S., Alexander, T.D., Goldsworthy, G. \& Carson, D.A., eds. New Dictionary of Biblical Theology. Downers Grove: InterVarsity. p. 52-64.)

VANHOOZER, K.J., ed. 2005. Dictionary for the Theological Interpretation of the Bible. Grand Rapids: Baker.

WALTERS, S., ed. 2008. Go figure! Figuration in biblical interpretation. Eugene: Pickwick.

WELLHAUSEN, J. 1885. Prolegomena to the history of Israel. Edinburgh: Black.

YARCHIN, W. 2004. History of biblical interpretation: a reader. Peabody: Hendrickson.

YOUNG, F. 1992. Alexandrian interpretation. (In Coggins, R.J. \& Houlden, J.L., eds. A Dictionary of Biblical Interpretation. London: SCM. p. 10-12.)

\section{Kernbegrippe:}

Bybelinterpretasie, geskiedenis van

gereformeerde teologie

grammaties-historiese eksegese

hermeneutiek

\section{Key concepts:}

biblical interpretation, history of

grammatical historical exegesis

hermeneutics

reformed theology 
